\title{
Experimental measurement of wave loads on a concrete multi chamber perforated caisson: a comparison between direct measurement and pressures integration
}

\author{
Alexandre CINELLO ${ }^{1}$, Benjamin BAILLY ${ }^{1}$, \\ François PETRIE ${ }^{1}$, Vincent LAFON ${ }^{1}$
}

\author{
1. Océanide, Port de Brégaillon, BP 63, 83502 La Seyne sur Mer, France \\ contact@oceanide.net; bbailly@oceanide.net
}

\begin{abstract}
:
Load measurement on a breakwater caisson can be achieved by two different methods: the direct measurements by mean of 3-Component (3C) balances and the integration of pressure measurements at different breakwater levels. Each measurement system has its pros and cons; requiring careful consideration on tests objectives and measurement system capabilities and limitations.

Both measurement methods were deployed on a multi chamber perforated caisson during a 3-D model test campaign. After a description of the experiments and a comparison of the loads issued from these two methods, this paper ends on a discussion concerning whether these measurements shall be considered as alternative or complementary approaches.
\end{abstract}

\section{Résumé :}

La mesure des efforts sur un caisson brise-lames peut être obtenue par deux méthodes différentes : la mesure directe au moyen de balances 3 composantes et l'intégration de pressions mesurées à différents emplacements sur le brise-lames. Chacune de ces deux méthodes présentent ses avantages et ses inconvénients; nécessitant un examen attentif des objectifs visés par les essais et des capacités et limites de chacun des systèmes de mesure.

Ces deux approches ont été déployées sur un caisson à paroi perforée composé de deux chambres lors d'une campagne d'essais sur modèle 3D. Après une description du dispositif expérimental et une comparaison des efforts obtenus par les deux méthodes, cet article termine sur une discussion sur la question de savoir si ces mesures doivent être considérées comme des approches alternatives ou complémentaires.

Mots-clés :

Modélisation physique, Monaco, Caisson à paroi perforée multi-chambres, Instrumentation, Balance 3C, Post-traitement des mesures, Effort, Moment 


\section{Thème 4 - Ouvrages portuaires, offshore et de plaisance}

\section{Introduction}

The assessment of global stability of a breakwater caisson requires the assumption of wave loads on the structure. To estimate these loads, several empirical or semi-empirical formulae exist. However, these design methods present some limitations in their application, in case of breaking waves and complex caisson geometry, and may lead to incorrect design loads. It is therefore a common industry practice to perform model tests to address this issue. Load measurement on a breakwater caisson can be achieved by two different methods:

a) Direct measurements by mean of $3 \mathrm{C}$ balances.

b) Integration of pressure measurements at different breakwater levels.

Both measurement methods were deployed during a 3-D model test campaign to determine the loads and moment acting on a multi chamber perforated breakwater caisson. This paper starts with the presentation of the project background and a description of the model tests campaign. The method used to extrapolate and integrate pressure measurements is then described. Finally, loads and moment extracted with these two approaches are compared in order to determine whether these measurement approaches shall be considered as being alternative or complementary.

\section{Description of the experiments}

\subsection{Background}

These model tests campaign comes within the offshore extension project of the Monaco heliport led by INGEROP, figure 1. This extension consists of 4 multi chambers perforated caissons to be installed in front of the existing ones to secure heliport operations. Objectives of this model tests campaign were to:

a) Investigate the impact of the new caissons on wave agitation in front of the Heliport.

b) Analyze wave overtopping with the new caissons shape.

c) Study the hydraulic stability of the new berm foundation.

d) Measure loads, moments and pressures under design sea-state conditions.

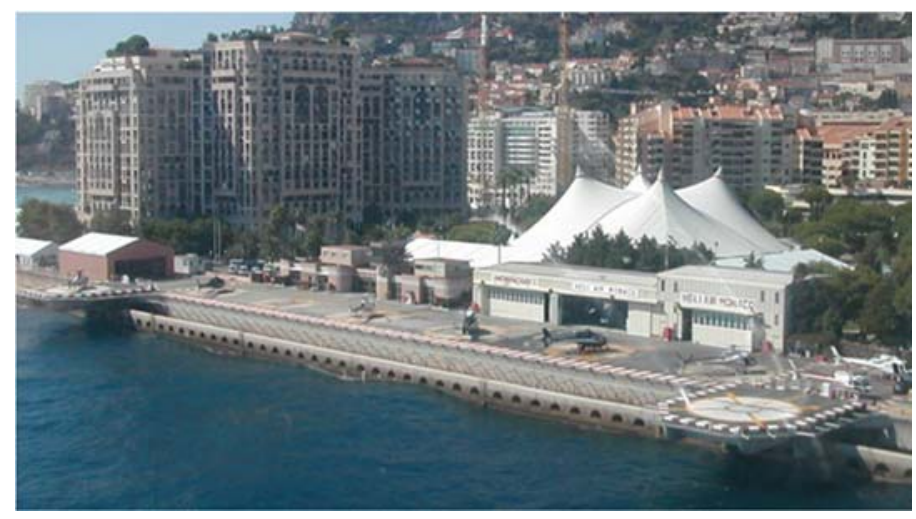

Figure 1. Monaco heliport. 


\section{XVIèmes Journées Nationales Génie Côtier - Génie Civil \\ Le Havre 2020}

\subsection{The facility}

These experiments have been carried out in the Océanide shallow water wave tank located in La Seyne sur Mer, south of France. The facility is $27.0 \mathrm{~m}$ long, $12.0 \mathrm{~m}$ width with an adjustable depth from $0 \mathrm{~m}$ to $1.0 \mathrm{~m}$. A floating type wave maker, installed across the entire tank's width, allows the generation of regular and irregular waves with periods from $0.6 \mathrm{~s}$ to $3 \mathrm{~s}$ and heights up to $0.5 \mathrm{~m}$ at model scale.

Note that in the following, all values are provided by default at full-scale.

\subsection{The model}

A 3-D physical model was built at a scale of 1:50 considering Froude similarity law, including the existing heliport and its future extension, figure 3.

The seabed bathymetry and the existing caisson berm were constructed in plywood based on profiles provided by INGEROP. The seabed is almost flat from offshore up to the berm with an approx. $50 \mathrm{~m}$ depth. The new berm foundation from $-15 \mathrm{~m}$ to $-30 \mathrm{~m}$ is represented with rock at scale. As recommended by the Rock Manual, the rock scaling is such that the stability parameter is equal in model and prototype.

Concrete caissons were built in wood and PVC. Existing caissons were painted in grey, while future extension, composed of 4 caissons, were painted in white. Each caisson is a box shape perforated caisson with two chambers. At a scale of 1:1, external dimensions are of about $30 \mathrm{~m}$ length, $20 \mathrm{~m}$ width and $20 \mathrm{~m}$ height. Internal chambers are $8.85 \mathrm{~m}$ width from +4.20 to $-5.40 \mathrm{mNGF}$.

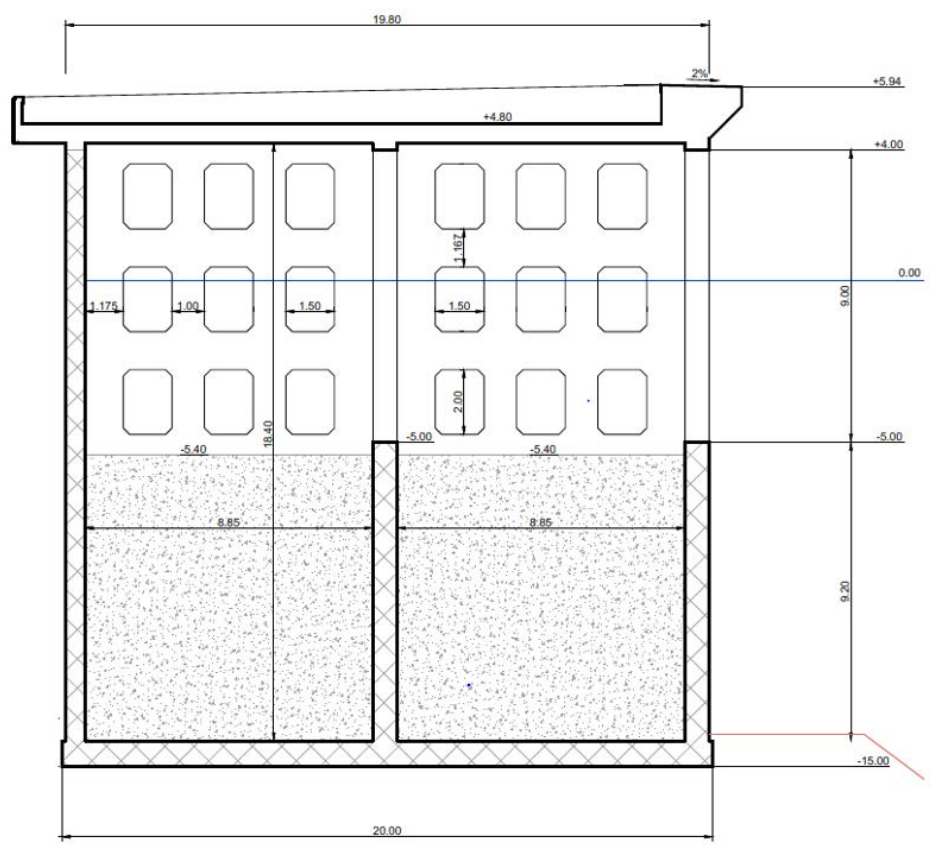

Figure 2. Cross section of the caisson to be modeled. 


\section{Thème 4 - Ouvrages portuaires, offshore et de plaisance}

External wall porosity is of $45 \%$ while internal wall porosity is of $30 \%$. Porosity is defined as the ratio of the area of the wall openings to the total wall area on the height of the openings.

Rock armour layers were installed based on specified cross sections and are split into 2 areas. A first area in front of caissons 1 and 2 are painted to check rocks stability. The rock armour in front of caissons 3 and 4 are fixed by a net to avoid interaction with loads measurements installed on caisson $n^{\circ} 3$. Caisson $n^{\circ} 3$ is separated from caissons 2 and 4 with an airgap of about $5 \mathrm{~mm}$ to avoid any interaction with load measurement. A flexible sealing gasket has been added on the seaside and on the slab edges to avoid non-realistic pressure transmission and therefore forces not representative of the real case.

Next pictures provide views of the model.
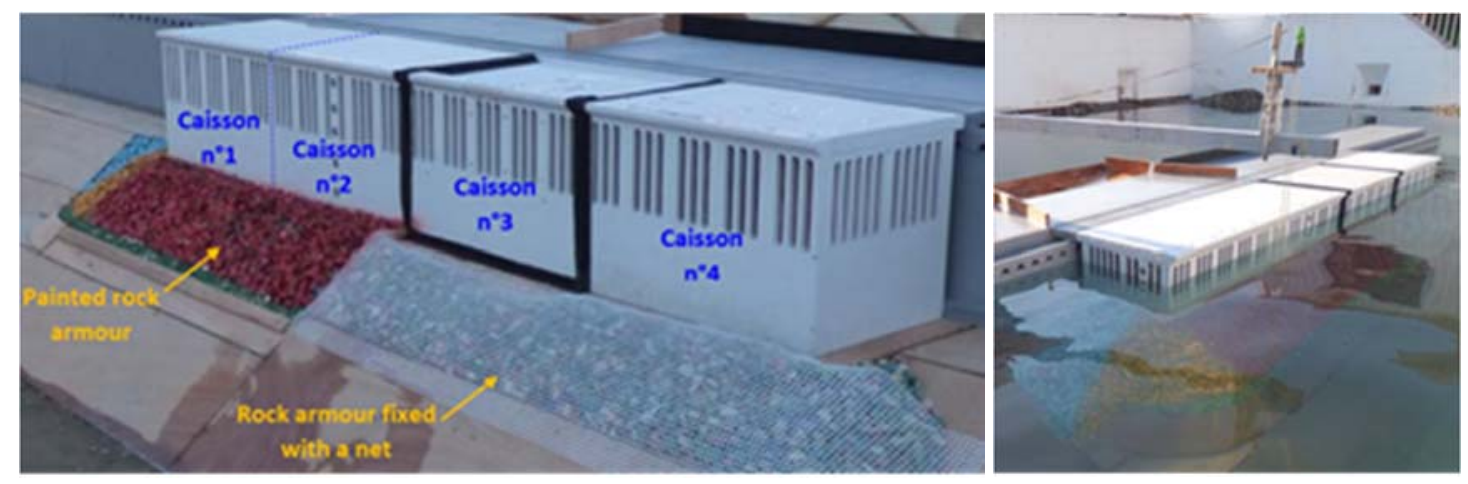

Figure 3. Views of the model.

\subsection{Tested conditions}

8 different irregular waves were considered for 2 different incidences (normal to the caissons and with a $42^{\circ}$ angle) together with 5 different water levels. The direction change was achieved by turning the entire model on the shallow water tank. Irregular waves were generated considering the JONSWAP spectrum with a shape parameter of 3.3. Wave significant heights were in a range from $3.5 \mathrm{~m}$ to $5.7 \mathrm{~m}$ and wave peak periods were in a range from $8 \mathrm{~s}$ to $12 \mathrm{~s}$.

\subsection{Measurements}

Separation of the incident and reflected waves is achieved thanks to a set of 5 probes located offshore at $550 \mathrm{~m}$ from the heliport caissons and installed inline along the wave propagation direction. The waves separation is performed in the frequency domain and is based on the method presented by GODA (1985). 2 wave gauges measured the wave elevation in front of the existing caisson and in front of the future caisson.

Special devices were used for measuring the wave overtopping volumes. Each device is composed of a small water tank which collects overtopping water on a $60 \mathrm{~m}$ width. One is located behind the existing caisson profile and the other one behind the future caisson 


\section{XVİ̀mes Journées Nationales Génie Côtier - Génie Civil \\ Le Havre 2020}

profile. Overtopping volume is determined by recording the water level in water tanks during the tests by means of a pressure gauge.

Damage progression of the rock armour was assessed for different wave conditions, making use of visual observation and photographic techniques.

A total of 11 pressure sensors (STS ATM.23 type) were attached to the model to measure the pressure variation during tests at various locations:

a) 5 of the them were located on the front wall of caisson $n^{\circ} 2$ numbered from P1 to P5, figure 4,

b) 4 on the internal wall of caisson $\mathrm{n}^{\circ} 2$ numbered from P6 to P9, see figure 4,

c) 2 on the internal floor of caisson $\mathrm{n}^{\circ} 2$ numbered P10 and P11.

3 panels fixed on the structure via a 1D load sensor (FUTEK LSB210 type) are used to capture the vertical pressure variation on seawall and covering slab of caisson $n^{\circ} 3(\mathrm{P} 16$, $\mathrm{P} 17$ and P18), see figure 5.

The horizontal Load (Fx), the vertical load (Fz) and the overturning moment (My) were measured on caisson $\mathrm{n}^{\circ} 3$ by mean of three 3C balances (AMTI MC3A type). Instrumentation assembly is totally designed by OCEANIDE with 3D drawing software, as shown on figure 6 for $3 \mathrm{C}$ balances, before model construction.
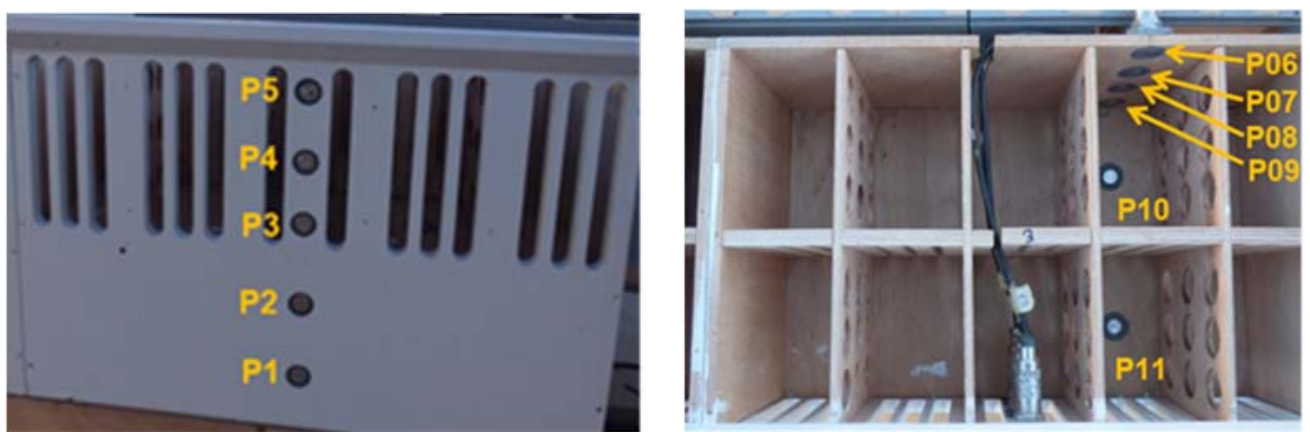

Figure 4. Pressure sensors on front wall (left) and on internal wall of caisson $n^{\circ} 2$.

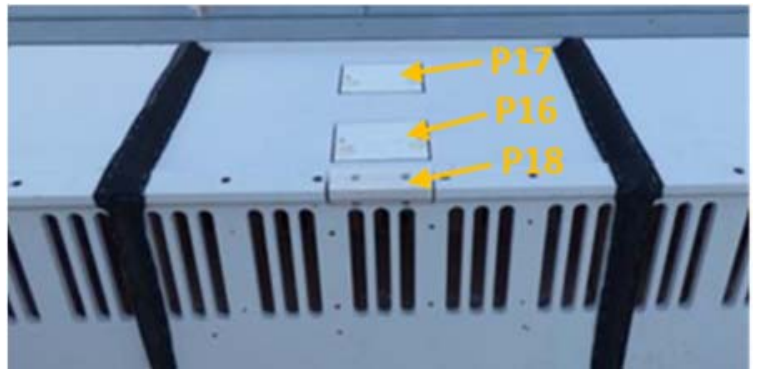

Figure 5. Pressure sensors on roof of caisson $n^{\circ} 3$. 


\section{Thème 4 - Ouvrages portuaires, offshore et de plaisance}
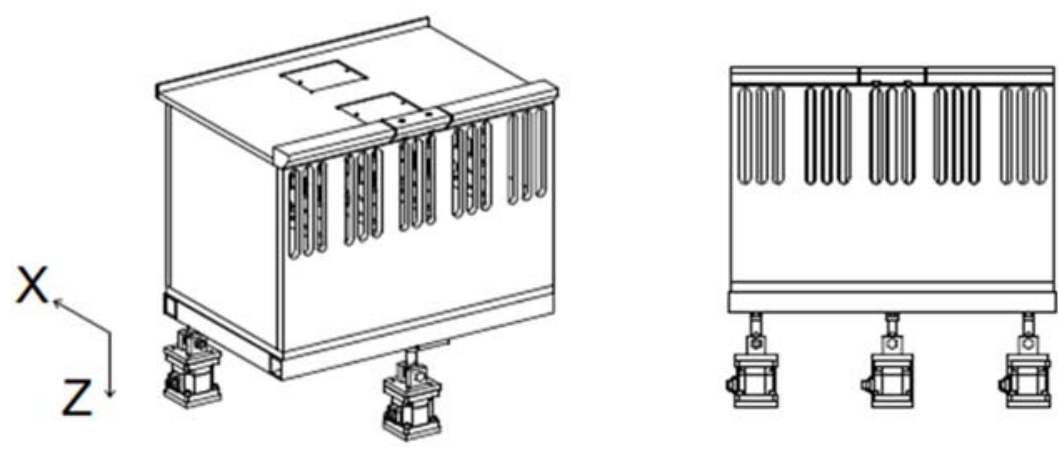

Figure 6. Design of 3C balances assembly for caisson $n^{\circ} 3$ with $3 D$ drawing software.

For instrumentation calibration the following has been performed:

a) Pressure sensor before 3D model assembly: verification of the pressure measured with the sensor immerged in various water depth.

b) 1D load sensor:

- before assembly: verification of loads with sensor stressed by various standard masses,

- once 3D model installed in the wave basin: hammer test and verification of loads with sensor stressed by various standard masses.

c) 3C balance:

- each $3 \mathrm{C}$ balance: verification of forces et moments with standard masses,

- caisson supporting frame with $3 \mathrm{C}$ balances assembly: verification of forces and moments with standard masses,

- caisson $n^{\circ} 3$ instrumented and installed in the wave basin: hammer test and verification of forces and moment with caisson stressed by a line tensioned by a precalibrated spring.

Finally, the acquisition frequency was set to $141.4 \mathrm{~Hz}$ full-scale, corresponding to $1000 \mathrm{~Hz}$ model scale. If required, acquisition frequency can be greatly increased by OCEANIDE.

\section{Loads and pressures measurements}

\subsection{Discussion}

The direct measurement approach measures the full caisson loads and moments through a set of load cells. The main advantages of such a device are its robustness, its easy deployment and the direct access to the true loads and moments on the caisson with respect to several degrees of freedom. However, direct measurement requires that the model is suspended and that a gap is left between the structure and its surroundings. This set-up will thus lead to vibrations of the structure submitted to impact loads. These small movements can lead to interactions with structure surroundings. In addition, the introduction of a gap below the breakwater may affect the quality of vertical loads 


\section{XVIèmes Journées Nationales Génie Côtier - Génie Civil \\ Le Havre 2020}

measurements. Finally, this kind of set-up do not allow the extraction of pressure distribution and measurement wave impact load as it is filtered by the mechanical system. The pressure measurement method presents the advantages of measuring the pressures distribution with a high frequency sampling and allow the access to actual wave impulsive load. In addition, the instrumentation deployed for this method does not affect the modelling of caisson surroundings such as the rubble mound foundation. However, this kind of sensors is intrusive, and measures pressure/loads only locally. Consequently, the calculation of loads and moments on the caisson require extrapolation between sensors across the caisson surface or, for structure with a complex geometry, many sensors that will make this solution difficult to implement. In addition, a preliminary assessment of the pressure distribution might be required for complex structures to determine the best sensors location.

Finally, as the full caisson loads and moments can be derived by integration of pressure measurements and as this approach allows the extraction of other valuable information such as the pressure distribution and the impulsive load induced by breaking wave, one question raised was whether the direct measurement still a relevant method to measure wave loading on a breakwater caisson.

\subsection{Post-treatment}

Load and moment on the caisson were recalculated from pressure measurements. The first step is to derive the pressure profiles on the 6 sides of the caisson based on the 14 local pressure/load measurements. These 6 sides, illustrated in figure 6 , are: the sea-side wall (S1), the land-side wall (S3), the caisson roof (S4), the caisson internal floor (S5), the internal wall (S2) and below the caisson base (S6). It is reminded here that the four first mentioned sides are instrumented.
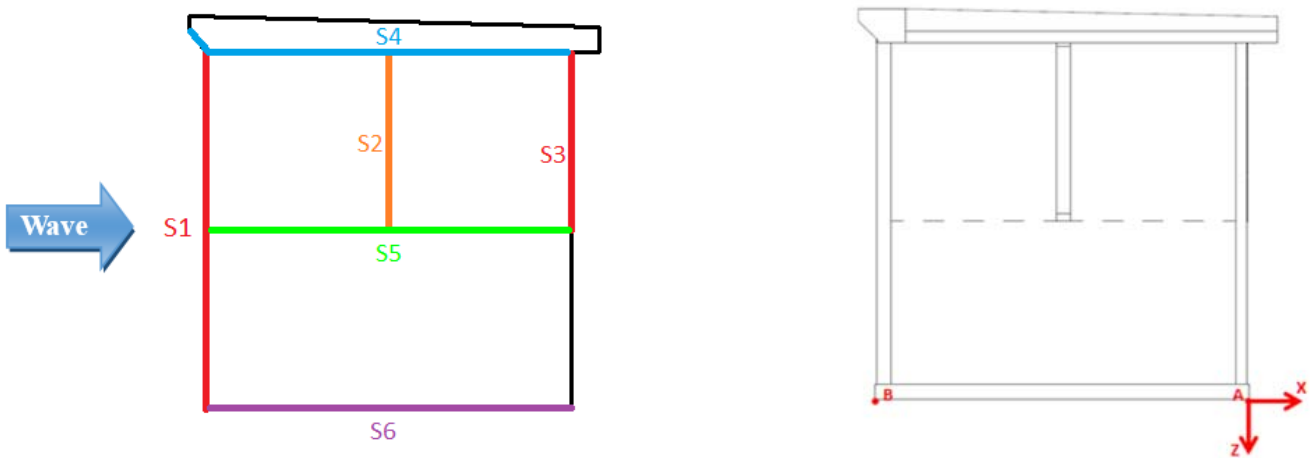

Figure 7. The 6 caisson sides (left) and reference frame (right).

The seaside and land-side vertical walls, in red on figure 7, have been discretized into:

a) 8 elevations for the front wall: 6 elevations corresponding to the locations of sensor P1 to P5 and sensor P18 and 2 extreme elevations noted B and B' in figure 8 (left), 


\section{Thème 4 - Ouvrages portuaires, offshore et de plaisance}

b) 6 elevations for the rear wall: 4 elevations corresponding to the locations of sensor P6 to $\mathrm{P} 9$ and 2 extreme elevations noted $\mathrm{C}$ and $\mathrm{C}^{\prime}$ in figure 8 (left).

The pressure value at each sensor elevation is taken equal to the measurement of the corresponding sensor. In between each sensor, a linear interpolation is considered. For the extreme points, the measurement of the closest sensor is considered. For example, at elevation B the pressure measurement of sensor P1 is considered.

For the covering slab and the internal floor, in blue and green respectively, pressures measured by sensors P10, P11, P16, P17 and P18 are applied uniformly on the corresponding horizontal wall.

The discretization of the internal wall is the same as the one applied to the land-side wall that is composed of 6 elevations. The pressure field on the internal wall P61, P71, P81 and P91, in orange, is calculated by linear interpolation between the computed pressure fields on the sea-side wall and on the land-side wall.

A triangular shape pressure field is applied below the caisson base as illustrated in figure 8 (right). The pressure measured at sensor P1 is applied at the sea-side edge. Then the pressure field decreases linearly down to a nil-value at the other edge. During the tests, the joint installed around the caisson base led to a nil-pressure variation below the caisson. This was confirmed by an additional pressure sensor installed below the caisson. Consequently, the vertical loads captured by the $3 \mathrm{C}$ balances is not representative of the actual case and was thus corrected by the triangular shape pressure field discussed herebefore. This concrete example illustrates the benefit of the hybrid approach used for this test i.e. the direct measurement method and pressure integration used in conjunction. The horizontal load, the vertical load and overturning moment are computed by pressure fields integration. It is mentioned that a coefficient of 0.45 is applied to the pressures P3, P4 and P5 to take into account the sea-side wall porosity and a coefficient of 0.3 is applied to the pressures P61, P71, P81 and P91 to take into account the internal wall porosity.
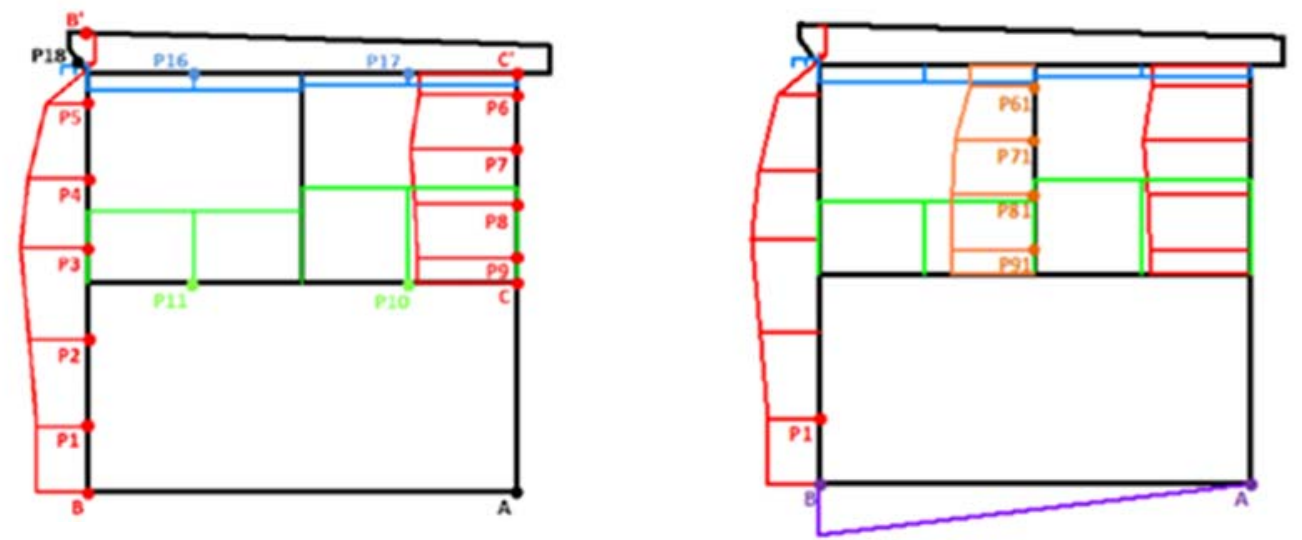

Figure 8. Pressure profiles on instrumented sides (left) and on internal wall and base. 


\section{XVIèmes Journées Nationales Génie Côtier - Génie Civil \\ Le Havre 2020}

\subsection{Experimental results}

Load and moment values are expressed in the reference frame presented at the beginning and have been averaged to be expressed in load/moment per meter.

Table 1 provides a comparison of the main results extracted from loads and moment measured by the $3 \mathrm{C}$ balances and computed by pressure integration. It includes the following statistics extracted from the 3-hours timeseries:

a) The standard deviations of the horizontal loads, vertical loads and overturning moments at points $\mathrm{A}$ and $\mathrm{B}$

b) The maximum horizontal load, vertical load and moment in point $\mathrm{B}$

c) The minimum moment in point $\mathrm{A}$.

Table 1. Loads and moment comparison.

\begin{tabular}{|c|c|c|c|c|c|c|c|c|c|}
\hline & \multicolumn{2}{|c|}{$\begin{array}{c}\mathrm{Fx} \\
{[\mathrm{kN} / \mathrm{ml}]}\end{array}$} & \multicolumn{2}{|c|}{$\begin{array}{c}\mathrm{Fz} \\
{[\mathrm{kN} / \mathrm{ml}]}\end{array}$} & \multicolumn{2}{|c|}{$\begin{array}{c}\text { MyA } \\
{[\mathrm{kN} \cdot \mathrm{m} / \mathrm{ml}]}\end{array}$} & \multicolumn{2}{|c|}{$\begin{array}{c}\text { MyB } \\
{[\mathrm{kN} \cdot \mathrm{m} / \mathrm{ml}]}\end{array}$} \\
\hline & & Max & Stdv & Max & Stdv & Min & Stdv & $\operatorname{Max}$ & Stdv \\
\hline \multirow{3}{*}{$\begin{array}{l}100 \text {-year } \\
\text { wave }\end{array}$} & 3D-balance & 1688 & 361 & 710 & 258 & -24683 & 4228 & 12197 & 3819 \\
\hline & Pressures & 2103 & 335 & 679 & 199 & -27138 & 4241 & 17132 & 4455 \\
\hline & Deviation & $25 \%$ & $-7 \%$ & $-4 \%$ & $-23 \%$ & $10 \%$ & $0 \%$ & $40 \%$ & $17 \%$ \\
\hline \multirow{3}{*}{$\begin{array}{l}10 \text {-year } \\
\text { wave }\end{array}$} & 3D-balance & 1081 & 264 & 661 & 209 & -20701 & 3142 & 8947 & 2982 \\
\hline & Pressures & 1619 & 254 & 474 & 173 & -23729 & 3289 & 11699 & 3174 \\
\hline & Deviation & $50 \%$ & $-4 \%$ & $-28 \%$ & $-17 \%$ & $15 \%$ & $5 \%$ & $31 \%$ & $6 \%$ \\
\hline \multirow{3}{*}{$\begin{array}{l}1 \text {-year } \\
\text { wave }\end{array}$} & 3D-balance & 520 & 133 & 477 & 125 & -8339 & 1499 & 5911 & 1888 \\
\hline & Pressures & 1007 & 128 & 417 & 125 & -12481 & 1830 & 8025 & 1656 \\
\hline & Deviation & $94 \%$ & $-4 \%$ & $-13 \%$ & $0 \%$ & $50 \%$ & $22 \%$ & $36 \%$ & $-12 \%$ \\
\hline
\end{tabular}

This comparison is supplemented by figures 9 and 10 which compare the time series on 100s duration around the load/moment extrema extracted by pressure integration. This comparison shows that loads and moments calculated from direct measurements and pressure integration exhibit very similar first order variation. However, differences are observed on extracted extrema. Horizontal load and moments extracted by pressures integration are higher than measured with the $3 \mathrm{C}$ balances, while vertical loads exhibit lower maximum values with the pressure integration approach.
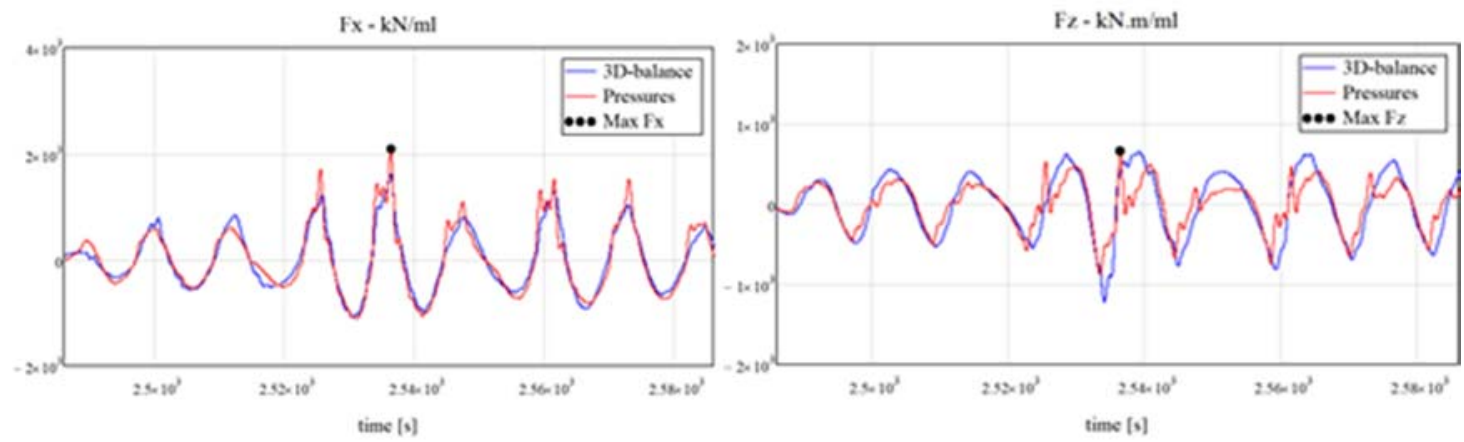

Figure 9. Horizontal (left) and vertical load right) comparison. 


\section{Thème 4 - Ouvrages portuaires, offshore et de plaisance}
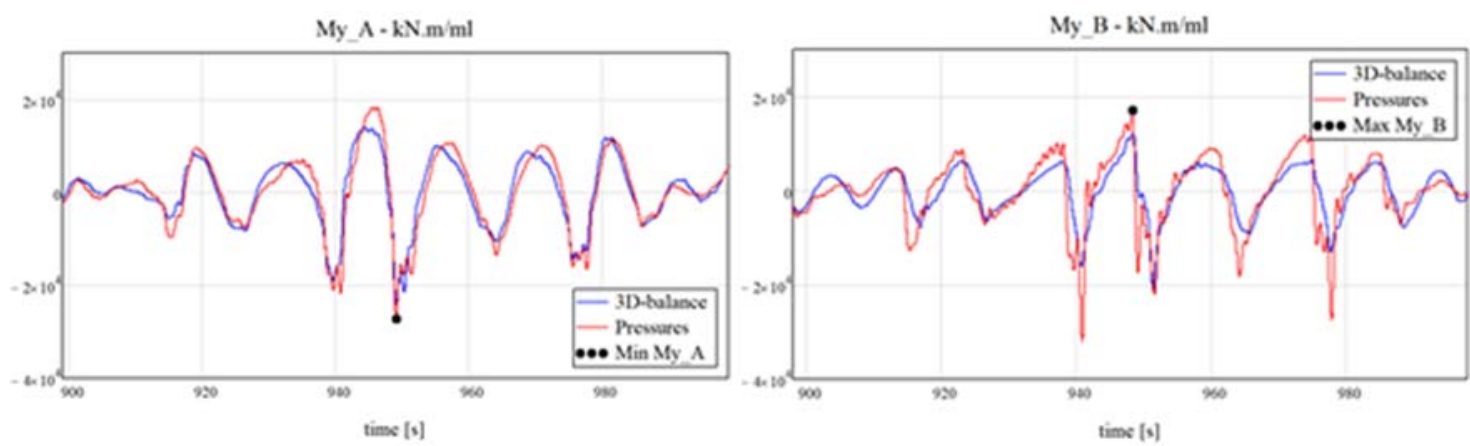

Figure 10. Overturning moment at point A (left) and point B (right) comparison.

The following reasons might explain these differences:

a) Firstly, pressures are measured locally while some variations can occur on the breakwater width, especially as the present tests are performed on a $3 \mathrm{D}$ model. Accuracy of load measurements can be improved by increasing the number of sensors; however, these sensors are intrusive, and their presence may affect the measurement quality. Consequently, sensors number and location are a balance between measurement accuracy and campaign budget and fabrication constraints.

b) Then, wave impacts loads are averaged over the surface of the caisson exposed to waves by the direct measurement method as the $3 \mathrm{C}$ balances assembly cannot measure local peaks of very short durations due to the measurement system proper inertia.

c) Finally, the vertical load measured by the direct method might be impacted by the gap let below the caisson.

Figures 11 and 12 give the instantaneous pressure profiles at the times of the four selected cases: maximum horizontal load, maximum vertical load, minimum moment in point $\mathrm{A}$ and maximum moment in point $B$. Note that these two moments correspond to the maximum landward overturning moment and the maximum seaward overturning moment respectively. From the load time series analysis, it appears that maximum horizontal landward loads are concomitant to maximum vertical downward loads. The examination of the pressure profiles of these two cases show that the pressure distribution leading to the maximum horizontal landward loads and the pressure distribution leading to the maximum vertical downward loads are very similar, leading thus to the concomitance of these two extreme loadings. 


\section{XVİ̀mes Journées Nationales Génie Côtier - Génie Civil \\ Le Havre 2020}
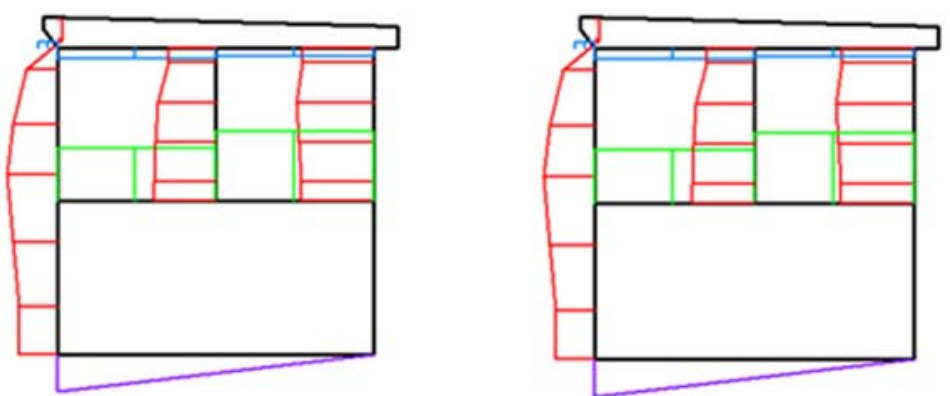

Figure 11. Maximum horizontal (left) and vertical (right) load: Pressures distribution.
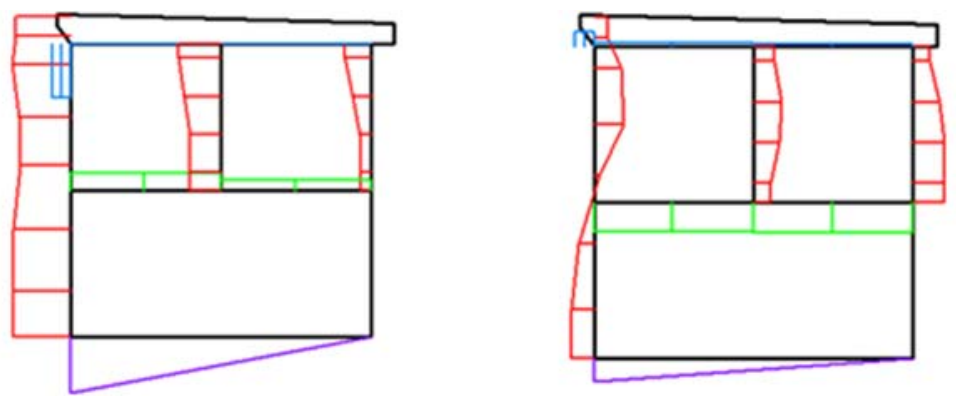

Figure 12. Minimum moment at point A (left) and B (right): Pressures distribution.

\section{Conclusions}

For a 2D campaign with a caisson of simple geometry and non-breaking wave conditions the use of pressure sensors can be enough to predict accurate full body load and moment. For other cases, it is recommended to use the direct load measurements and pressure measurements in conjunction. Indeed, the use of pressure integration approach alone will lead to many sensors to accurately capture loads and moments. Furthermore, the use of direct measurement will not allow the measurement of high impulsive loadings. In addition, and as shown in the present paper, the use of pressure sensors complements the direct load measurement; e.g. to correct the vertical load using below pressure measurements and to explain/investigate some specific phenomena (concomitance of extreme loadings in the present case). Finally, while pressures measurement at different level aims at assessing the actual wave impact load and will be used for structural design, the direct measurement provides the 'reaction force' that shall be used for stability analysis.

One of the main advantages of the pressure measurements is to provide a complete picture of the impact process in time and space. This detailed description is of interest for certain design purpose, such as the concrete design of breakwater side and internal walls, crown wall and covering slab of the caisson.

Finally, the measurements performed during this campaign add to a significant list of similar experimental works (in 3D or 2D) produced by OCEANIDE. The extracted data supplement the existing internal database that can be used by OCEANIDE to compare physical model results and the results provided by the application of the GODA (1985) 
Thème 4 - Ouvrages portuaires, offshore et de plaisance

wave pressure formulae modified by TAKAHASHI (TAKAHASHI, 1996; CEM, 2011) frequently applied to preliminary estimate loads and moments on perforated breakwater caissons. This database offers the possibility to OCEANIDE's clients to tune their analytical models if required.

\section{References}

GŌDA Y. (1985). Random seas and design of maritime structures. University of Tokyo Press, $323 \mathrm{p}$.

TAKAHASHI S. (1996). Design of vertical breakwaters - Port and Airport Research Institute, Japan, revised in July 2002, version 2.1, 110 p.

CEM (2011). Coastal Engineering Manual, EM 1110-2-1100 - Part VI - Fundamentals of design - Chapter 5 - Change 3 (28 September 2011), US Army Corps of Engineers, Engineering and design, $771 \mathrm{p}$. 